\title{
First Notes on Reproduction of Cuban Snakes in the Endemic Genus Arrhyton Günther 1858 (Squamata: Dipsadidae)
}

\author{
Seriocha Amaro-Valdés ${ }^{1}$ and Ernesto Morell-Savall ${ }^{2}$ \\ ${ }^{1}$ Instituto de Ecología y Sistemática, Carretera de Varona, \# 11835, / Oriente y Lindero, Reparto Parajón, Municipio Boyeros, \\ La Habana 19, CP 11900, Cuba (amaro@ecologia.cu) \\ ${ }^{2}$ Reserva Florística Manejada “Sabanas de Santa Clara," Empresa Nacional para la Protección de la Flora y la Fauna, \\ Villa Clara, CP 50100, Cuba (ernestomorell68@nauta.cu)
}

Photographs by the senior author.

$\mathrm{T}$ he genus Arrhyton Günther 1858 is endemic to Cuba (Hedges et al. 2009; Zaher et al. 2009). Five of the eight currently recognized species $(62.5 \%)$ have restricted geographical distributions and have been listed as threatened according to IUCN Red List categories (IUCN-SSC 2012). Principal threats are habitat fragmentation and loss (Rodríguez and Chamizo 2000; Amaro 2012a, b, c, d, e, f). The other three species have wider distributions and currently are of least concern. Two of these (Fig. 1), the Cuban Short-tailed Racerlet, Arrhyton vittatum (Gundlach and Peters 1862), and the Broad-striped Racerlet, A. taeniatum Günther 1858, the latter the largest species in the genus (Henderson and Powell 2009), are the subjects of this study.

Arrhyton vittatum has a disjunct distribution across much of Cuba (absent only from the provinces of Guantánamo, Santiago de Cuba, and Granma) and Isla de la Juventud (Schwartz and Garrido 1981; Amaro 2005). Reports of locality records in southeastern Cuba (Schmidt 1920; Alayo 1951; Rodríguez et al. 2013) were misidentifications. Arrhyton taeniatum also has a broad and disjunct distribution on Cuba and occurs on Isla de la Juventud plus the Cayos Coco and Sabinal in the Camagüey Archipelago (Schwartz and Garrido 1981; Estrada 1993, 2012; Amaro 2005). Barbour and Ramsden (1919) estimated that $A$. vittatum was somewhat more abundant than $A$. taeniatum, a contention supported by the greater abundance of the former in zoological collections (Schwartz and Garrido 1981; Rodríguez et al. 2014).

Little is known about the snakes of this genus, even those with a wider geographical distribution. This is largely attributable to infrequent observations due to their nocturnal and semifossorial habits. Essentially nothing is known about reproduction (Barbour and Ramsden 1919; Grant et al. 1959; Schwartz and Garrido 1981; Schwartz and Henderson

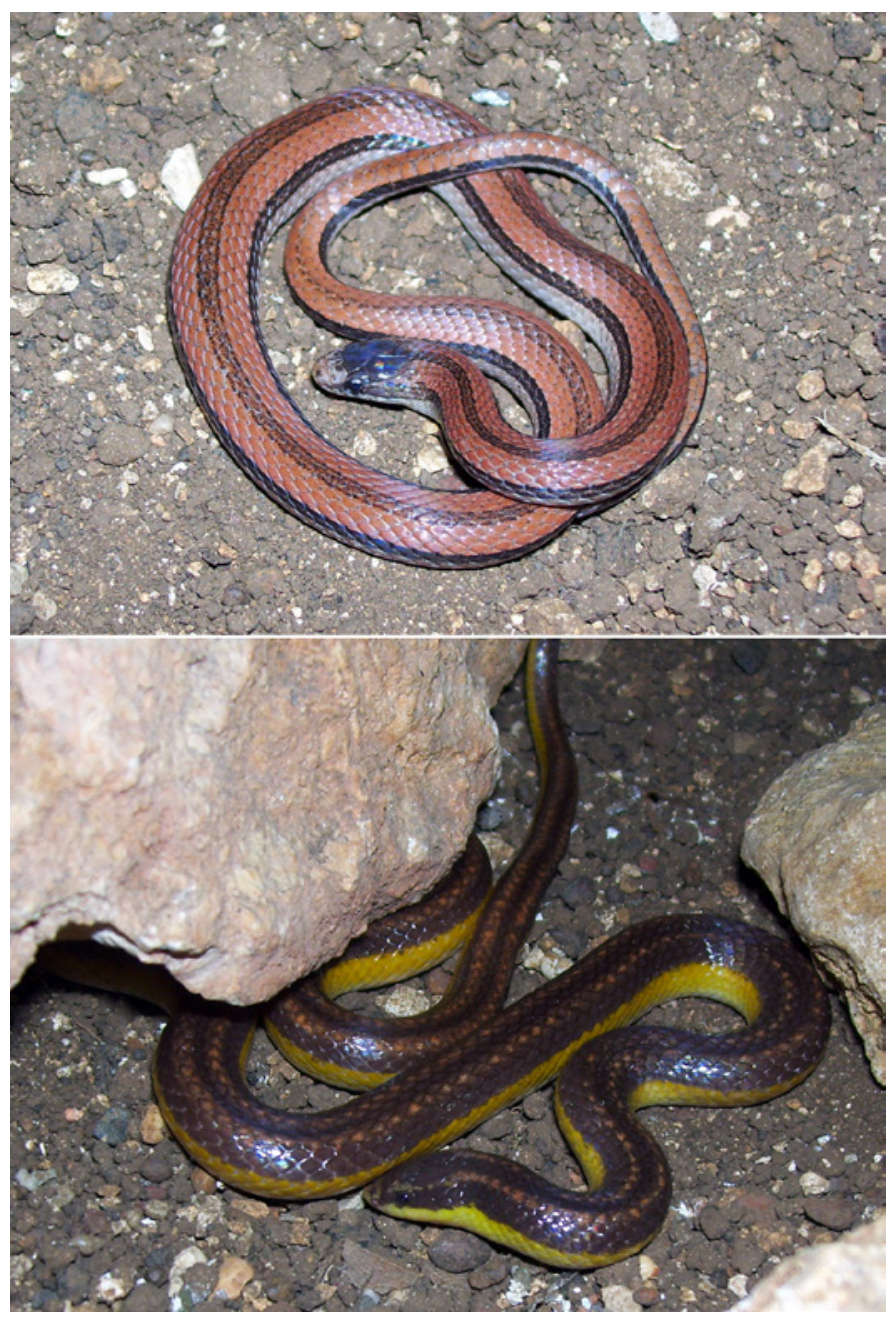

Fig. 1. Adult Short-tailed Racerlet (Arrhyton vittatum; top), collected in Habana del Este, La Habana Province, Cuba, in captivity; adult Broadstriped Racerlet (Arrhyton taeniatum; bottom), collected in La Movida, Protected Area Sabanas de Santa Clara, Villa Clara Province, Cuba, in captivity. 
1991; Amaro 2005; Henderson and Powell 2009). Published information on some aspects of the reproductive biology of Arrhyton in Cuba (Domínguez and Moreno 2003) was based largely on data pertaining to the Puerto Rican Racerlet (Magliophis stabli), which had previously been assigned to the genus Arrhyton (e.g., Schwartz and Henderson 1991; Rivero 1998).

On 5 April 2008, a female Arrhyton vittatum was collected in a patch of natural vegetation in the Parque Zoológico Nacional de Cuba (PZNC, 2302'03”N, 82 23'09”W), Boyeros Municipality, La Habana Province. On 3 May and 3 June 2008, two gravid female $A$. vittatum were collected at the Reserva Florística Manejada "Sabanas de Santa Clara" (RFMSS, $22^{\circ} 24^{\prime} 12^{\prime \prime N}$, 7957’07”W), Santa Clara Municipality, Villa Clara Province. All were housed in glass terraria 40 × 20 × 30 $\mathrm{cm}$ (females RFMSS) with a substrate of serpentine derived soil and 59.5 × 30.4 × $30.8 \mathrm{~cm}$ (female PZNC) with common brown soil. Substrates were occasionally moistened during the night. Water was provided ad libitum.

The females from the Protected Area Sabanas de Santa Clara each laid three eggs on 1 June and 29 June 2008, 28 and 26 days respectively after the collection date. The female from the zoo laid two eggs on 18 August 2008, four months and 13 days after the collection date; consequently, although we cannot rule out the possibility of sperm storage, we assume that copulation (not observed) occurred in captivity since this female, was kept with some conspecifics for several weeks immediately after collection.

All $A$. vittatum eggs were entirely white, ellipsoidal, and covered entirely with small projections. All were laid separately, not in clusters or adherent as has been described for other species of the tribe Alsophiini (Novo and Arazoza 1986; Rivero 1998; Fong and Garcés 2002; Fong 2004; Arango 2009; Rodríguez-Cabrera et al. 2015). We presume that, unlike other Cuban dipsadids, Cubophis cantherigerus and Caraiba andreae (Novo and Arazoza 1986; RodríguezCabrera et al. 2015), the number of eggs laid by females of A. vittatum is not proportional to the total length of females (Table 1).

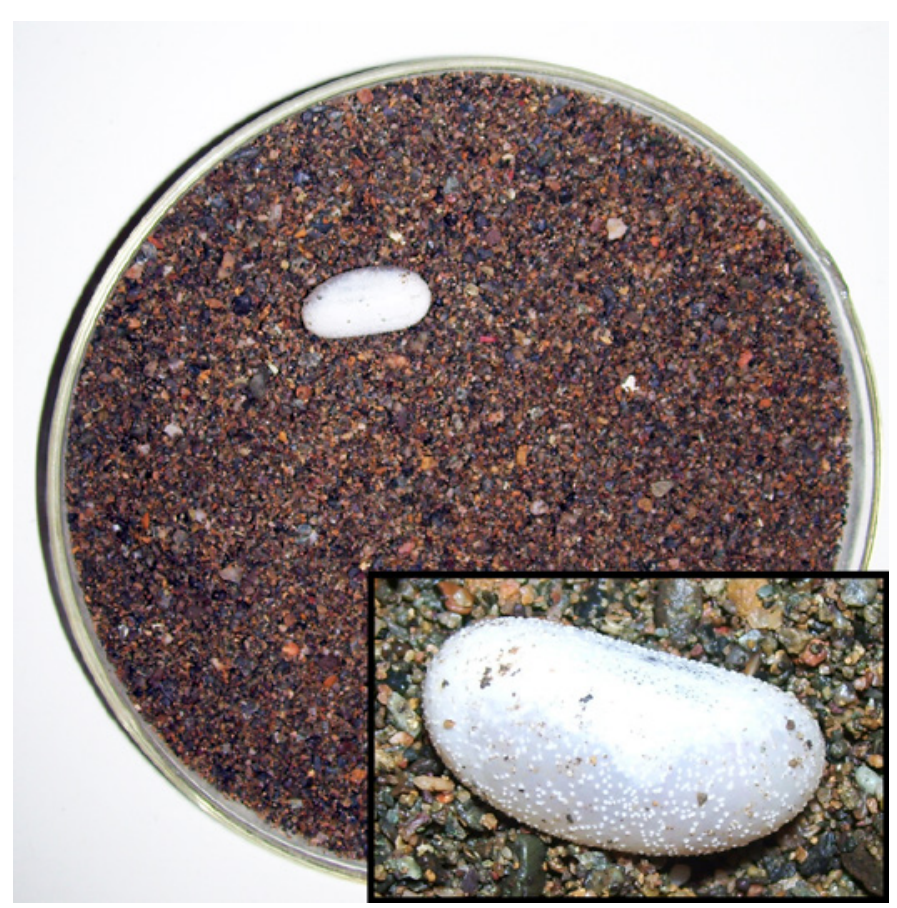

Fig. 2. Fertile egg of a Short-tailed Racerlet (Arrhyton vittatum; from female No. 3, Table 1) in incubation; insert: close-up view of the same egg showing ornamentation.

Eggs laid by females from the protected area Sabanas de Santa Clara were incubated in the terrarium (substrate: serpentine derived soil) where the females were housed. Eggs laid by the female from the zoo were incubated in Petri dishes (diameter $150 \mathrm{~mm}$, depth $20 \mathrm{~mm}$ ) with occasionally-moistened river sand as the incubation substrate (Fig. 2). In both instances, eggs were incubated at ambient temperature $\left(-28^{\circ} \mathrm{C}\right)$.

We measured only the two eggs laid by the female from the zoo (Stainless Steel Vernier Caliper to the nearest 0.1 $\mathrm{mm}$ ) and weighed (Portable Electronic Balance to the nearest $0.01 \mathrm{~g}$ ) a few hours after they were laid. The eggs were $18.8 \times 8.0 \mathrm{~mm}$ and $19.5 \times 7.9 \mathrm{~mm}$ and both weighed $0.7 \mathrm{~g}$. Five weeks after deposition, the second egg increased in size to $22.4 \mathrm{x} 11.5 \mathrm{~mm}$ and the first egg turned out to be infertile. Shell ornamentations (Fig. 2) were more evident after enlarg-

Table 1. Reproductive data from three female Short-tailed Racerlets (Arrhyton vittatum) and their hatchlings.

\begin{tabular}{lcccccc}
\hline Females & Total Length & Total Eggs & Infertile Eggs & Incubation & Hatchling Total & Hatchling \\
\hline & $(\mathrm{mm})$ & & Time (days) & Length $(\mathrm{mm})$ & Weight $(\mathrm{g})$ \\
\hline 1 RFMSS & 194 & 3 & 1 & 54 & $110-100$ & $0.5-0.6$ \\
\hline 2 RFMSS & 181 & 3 & 2 & 54 & 100 & 0.4 \\
\hline 3 PZNC & 331 & 2 & 1 & 49 & 102 & 0.6 \\
\hline
\end{tabular}




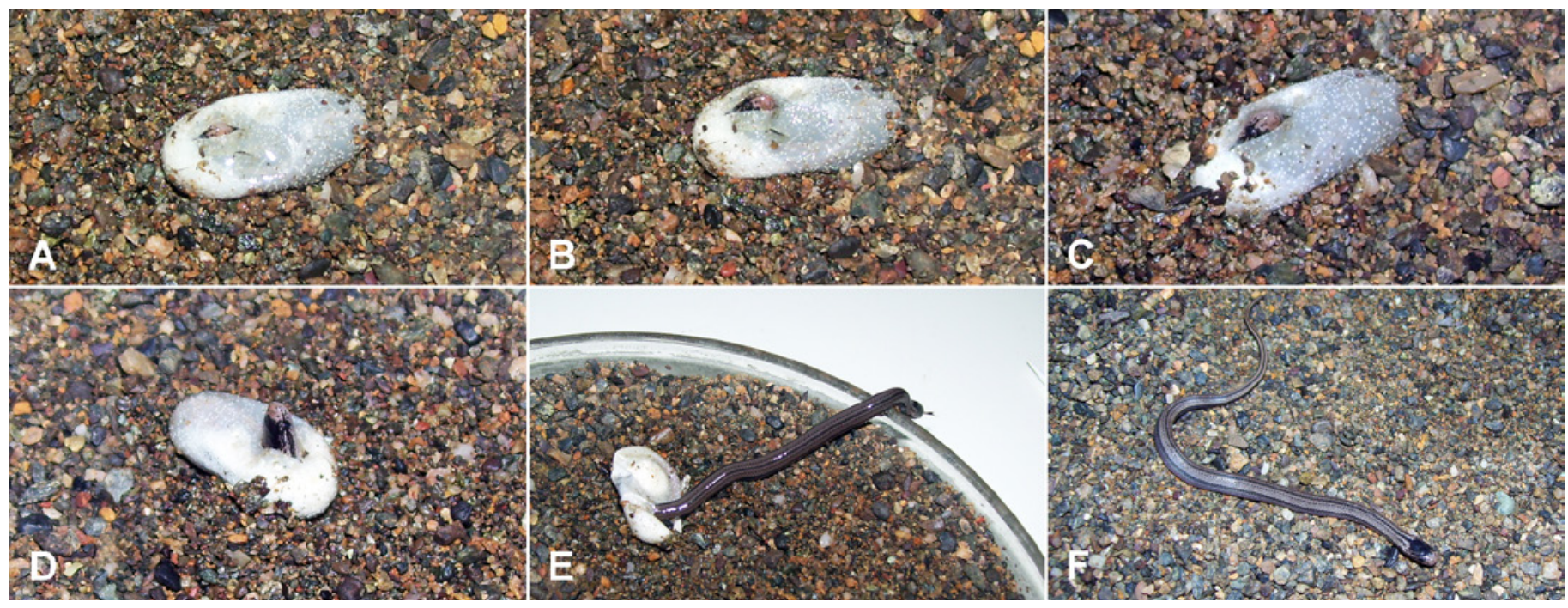

Fig. 3. Sequential stages of hatching in a Short-tailed Racerlet (Arrhyton vittatum; from female No. 3, Table 1): (A) rupture of egg showing hatchling snout on 5 October 2008; (B-D) head emergence; (E) body emergence; (F) hatchling on incubation substrate.

ment. Hatching began at 2355 h on 5 October 2008 and ended during the late hours of the night the following day, 49 days after deposition. Sequential stages during hatching are illustrated in Fig. 3. Duration of incubation and total lengths and weights of hatchlings are provided in Table 1.

Hatchlings had a brown to grayish-brown dorsal ground color (Fig. 3f) somewhat darker than in adults. After the first shedding, which occurred on day 6 after hatching in one of the hatchlings (from female No. 3, Table 1), coloration became lighter (Fig. 4). Ventral coloration was white, similar to adults. In one hatchling (Fig. 4), two much narrower brown stripes bordered the middorsal stripe; these two stripes were absent in the other hatchlings.

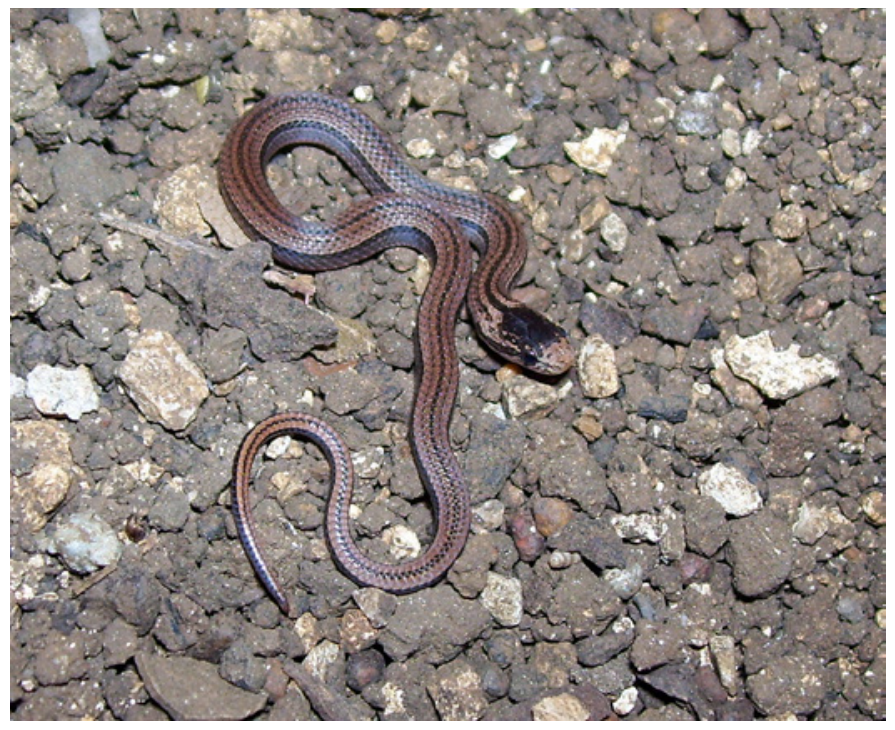

Fig. 4. Color pattern in a hatchling Short-tailed Racerlet (Arrhyton vittatum) from female No. 3 (Table 1).

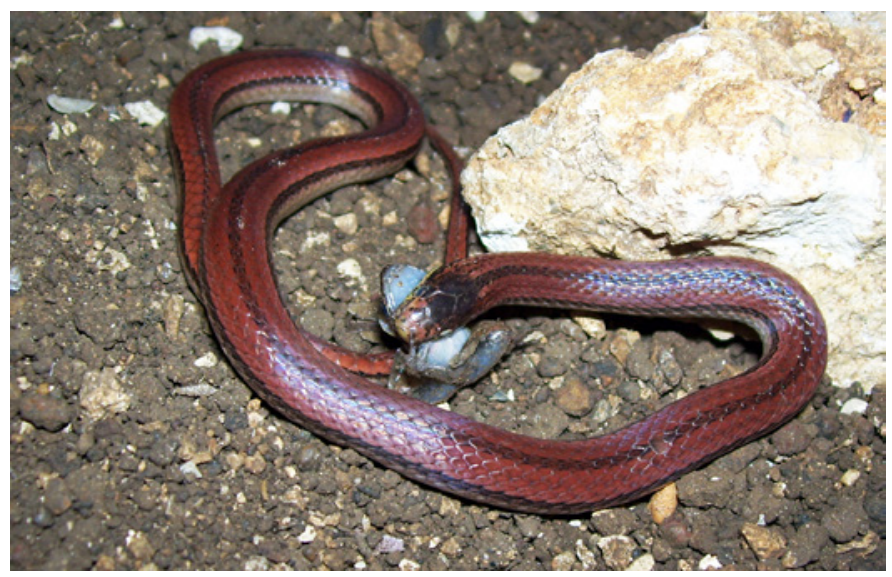

Fig. 5. Adult female Short-tailed Racerlet (Arrhyton vittatum) preying on an adult Cuban Flat-headed Frog (Eleutherodactylus planirostris, female No. 3, Table 1).

We offered juvenile Cuban Flat-headed Frogs (Eleutherodactylus planirostris) and lizard eggs (Anolis sp.), but no hatchlings accepted food. One adult female ate an adult E. planirostris (Fig. 5) and another ate an Anolis egg. Amaro (2005) listed other prey included in the diet of this species and $A$. taeniatum.

A gravid female Arrhyton vittatum, collected on 4 August 2005 in Habana del Este Municipality, La Habana Province, laid two eggs in a terrarium at night $(-2000-2100 \mathrm{~h})$ on 12 August 2005 (Ramsés A. Alonso, pers. comm., 2005). Javier Torres (pers. comm., 2016) collected a gravid female A. vittatum (no locality data) that laid two eggs at $2225 \mathrm{~h}$ and 2355 $\mathrm{h}$ on 18 June 2016. In both instances, eggs were white, ornamented, and laid singly; however, no eggs hatched. Another adult female $A$. vittatum, gravid and before shedding (Fig. 6), was collected in October 2011 in the northern part of Presa 


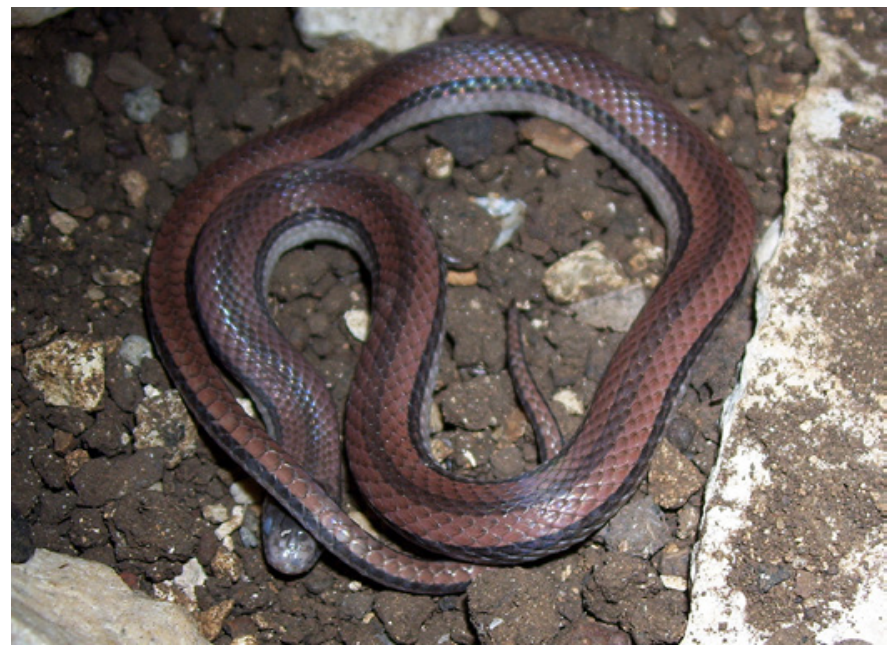

Fig. 6. Adult female Short-tailed Racerlet (Arrhyton vittatum) before shedding.

Minerva, Santa Clara Municipality, Villa Clara Province, but died in captivity after three days; it contained three eggs.

Information about the reproductive biology of Arrhyton taeniatum is more limited. An adult gravid female measuring $570 \mathrm{~mm}$ in total length was collected on 2 June 2008 in La Yagruma, Reserva Florística Manejada "Sabanas de Santa Clara." She laid three white ornamented eggs (not measured or weighed) 34 days after collection. No eggs hatched. An adult gravid female measuring $530 \mathrm{~mm}$ in total length (Alberto R. Estrada Collection, CARE 60926; examinated in April 2005) was collected on 7 June 1996 on the northern slope of Loma Canasí, Santa Cruz del Norte Municipality, Mayabeque Province; it contained two or three eggs.

\section{Acknowledgements}

The senior author thanks Luis M. Díaz, curator of the herpetological collection of the Museo Nacional de Historia Natural de Cuba for allowing access to the specimens of Arrhyton in April 2005. We are grateful to Ramsés A. Alonso for information and Javier Torres (Facultad de Biología, Universidad de La Habana) for editing the photographs, information, and suggestions on the first draft of this manuscript. We thank our colleague Pedro P. Herrera for helping with the English translation.

\section{Literature Cited}

Alayo D[almau]., P. 1951. Especies herpetológicas halladas en Santiago de Cuba. Boletín de Historia Natural de la Sociedad Felipe Poey 2: 106-110.

Amaro Valdés, S. 2005. Compilación y actualización de la información sobre las serpientes del género Arrhyton Günther, 1858 (Serpentes: Colubridae) con observaciones preliminares sobre el mantenimiento en cautividad de una de las especies cubanas. Tesis de Diploma, Facultad de Biología, Universidad de La Habana, Cuba.

Amaro Valdés, S. 2012a. Lista Roja de la fauna cubana. Editorial AMA, La Habana (www.snap.culhtml/descargas_decretos_resoluciones.htm).

Amaro Valdés, S. 2012b. Arrhyton ainictum, pp. 164-165. In: H. González Alonso, L. Rodríguez Schettino, A. González, C.A. Mancina, and I. Ramos García (eds.), Libro Rojo de los vertebrados de Cuba. Editorial Academia, La Habana.
Amaro Valdés, S. 2012c. Arrhyton dolichura, pp. 165-166. In: H. González Alonso, L. Rodríguez Schettino, A. González, C.A. Mancina, and I. Ramos García (eds.), Libro Rojo de los vertebrados de Cuba. Editorial Academia, La Habana.

Amaro Valdés, S. 2012d. Arrhyton procerum, pp. 166-167. In: H. González Alonso, L. Rodríguez Schettino, A. González, C.A. Mancina, and I. Ramos García (eds.), Libro Rojo de los vertebrados de Cuba. Editorial Academia, La Habana.

Amaro Valdés, S. 2012e. Arrhyton supernum, pp. 167-169. In: H. González Alonso, L. Rodríguez Schettino, A. González, C.A. Mancina, and I. Ramos García (eds.), Libro Rojo de los vertebrados de Cuba. Editorial Academia, La Habana.

Amaro Valdés, S. 2012f. Arrhyton tanyplectum, pp. 169-170. In: H. González Alonso, L. Rodríguez Schettino, A. González, C.A. Mancina, and I. Ramos García (eds.), Libro Rojo de los vertebrados de Cuba. Editorial Academia, La Habana.

Arango Leyva, A. 2009 [2008]. Reproducción en cautiverio de Alsophis cantherigerus schwartzi Lando y Williams, 1969 (Serpentes, Colubridae) en el Parque Zoológico Nacional de Cuba. Cubazoo 18: 3-6.

Barbour, T. and C.T. Ramsden. 1919. The herpetology of Cuba. Memoirs of the Museum of Comparative Zoology 47: 71-213.

Domínguez Díaz, M. and L.V. Moreno García. 2003. Serpientes del suelo, pp. 98-109. In: L. Rodríguez Schettino (ed.), Anfibios y Reptiles de Cuba. UPC Print, Vaasa, Finland.

Estrada, A.R. 1993. Anfibios y reptiles de Cayo Coco, Archipiélago de SabanaCamagüey, Cuba. Poeyana 432: 1-21.

Estrada, A.R. 2012. The Cuban Archipelago, pp. 113-125. In: R. Powell and R.W. Henderson (eds.), Island lists of West Indian amphibians and reptiles. Bulletin of the Florida Museum of Natural History 51: 85-166.

Fong G., A. 2004. Antillophis andreae (Black and White Racer, Jubito). Reproduction. Herpetological Review 35: 57.

Fong G., A. and G. Garcés G. 2002. Alsophis cantherigerus, mantenimiento y reproducción. Reptilia 34: 55-57.

Grant, C., H.M. Smith, and P. Alayo Dalmau. 1959. The status of snakes of the genus Arrhyton in Cuba. Herpetologica 15: 129-133.

Hedges, S.B., A. Couloux, and N. Vidal. 2009. Molecular phylogeny, classification, and biogeography of West Indian racer snakes of the tribe Alsophiini (Squamata, Dipsadidae, Xenodontinae). Zootoxa 2067: 1-28.

Henderson, R.W. and R. Powell. 2009. Natural History of West Indian Reptiles and Amphibians. University Press of Florida, Gainesville.

IUCN-SSC (International Union for Conservation of Nature Species Survival Commission). 2012. IUCN Red List Categories and Criteria. Version 3.1. 2nd ed. IUCN, Gland, Switzerland (http://s3.amazonaws.com/iucnredlistnewcms/staging/public/attachments/3097/redlist_cats_crit_en.pdf).

Novo Rodríguez, J. and F. de Arazoza Rodríguez. 1986. Cría en cautiverio de Alsophis cantherigerus (Ophidia: Colubridae). Reporte de Investigación del Instituto de Ecología y Sistemática 30: 1-15.

Rivero, J.A. 1998. Los anfibios y reptiles de Puerto Rico / The Amphibians and Reptiles of Puerto Rico. 2nd ed. rev., Editorial de la Universidad de Puerto Rico, San Juan.

Rodríguez-Cabrera, T.M., A. Arango Leyva, E. Morell Savall, J. Torres, and R. Marrero. 2015. Notes on reproduction of the Cuban Lesser Racer, Caraiba andreae (Squamata: Dipsadidae). Reptiles \& Amphibians 22: 1-7.

Rodríguez Schettino, L. and A.R. Chamizo Lara. 2000 [1998]. Reptiles cubanos con algún grado de amenaza de extinción. Poeyana 463: 1-8.

Rodríguez Schettino, L., C.A. Mancina, and V. Rivalta González. 2013. Reptiles of Cuba: Checklist and geographic distributions. Smithsonian Herpetological Information Service 144: 1-92.

Rodríguez-S[chettino]., L., V. Rivalta-G[onzález]., and A. González-C. 2014. Colección herpetológica del Instituto de Ecología y Sistemática, La Habana, Cuba. Familia Dipsadidae, géneros Arrhyton y Cubophis, familia Boidae, género Chilabothrus. Revista Colombiana de Ciencia Animal 6: 14-37.

Schmidt, K.P. 1920. Some new and rare amphibians and reptiles from Cuba. Proceedings of the Linnean Society 33: 3-6.

Schwartz, A. and O.H. Garrido. 1981. A review of the Cuban members of the genus Arrhyton (Reptilia, Serpentes, Colubridae). Annals of Carnegie Museum of Natural History 50: 207-230.

Schwartz, A. and R.W. Henderson. 1991. Amphibians and Reptiles of the West Indies: Descriptions, Distributions, and Natural History. University of Florida Press, Gainesville.

Zaher, H., F.G. Grazziotin, J.E. Cadle, R.W. Murphy, J.C. de Moura-Leite, and S.L. Bonatto. 2009. Molecular phylogeny of advanced snakes (Serpentes, Caenophidia) with an emphasis on South American xenodontines: A revised classification and descriptions of new taxa. Papéis Avulsos de Zoologia 49: 115-153. 